J. Natn. Sci. Foundation Sri Lanka 2001 29(3\&4): 137-145

\title{
PREPARATION AND CHARACTERIZATION OF EDIBLE SOYA PROTEIN FILMS
}

\author{
DUMINDA SHIROMALEE LIYANAGE ${ }^{* 1}$, MANGALA TILLEKERATNE ${ }^{* 2}$ and \\ SUJATHA HEWAGE ${ }^{1}$ \\ ${ }^{1}$ Department of Chemistry, Faculty of Science, University of Colombo, Colombo \\ ${ }^{2}$ Sir John Kotelawala Defense Academy, Kandawala Estate, Ratmalana
}

(Received: 03 October 2000; accepted: 18 February 2002)

\begin{abstract}
Soya bean has more protein (about $38-44 \%$ ) than the protein content (8 $15 \%$ ) of cereal grains. Most of the protein of soya is classified as globulin and is available as a low cost co-product of the oil processing industry. Although soya protein has been studied in combination with other proteins such as wheat giuten, the film forming ability of the soya protein isolate alone has not been studied in detail. In this report, the thermal, mechanical and water sorption properties of soya protein films are discussed. Water was used as the solvent to make casting solutions and glycerol was used as the plasticizer. The $\mathrm{pH}$ of the casting solution was adjusted by adding $2 \mathrm{M} \mathrm{HCl}$. Similar to other grain protein films, the properties of the soya protein isolate film largely depend on the relative humidity of the environment. Tensile strength values of soya protein films were found to be comparable with those of conventional packaging materials such as low density polyethylene. Moisture absorption isotherms were found to be similar in behavior to other proteins such as zein, wheat, gluten, etc. These values fitted well to the GAB modei proposed for the moisture absorption of grain proteins.
\end{abstract}

Key Words: film properties, glycerol, plasticizers, soya protein isolate (SPI).

\section{INTRODUCTION}

Environmental pollution caused by synthetic non-degradable polymer waste has reached alarming levels. In order to battle this global problem, increased interest has been directed towards the development of biodegradable polymers. Biodegradable films have attracted increasing interest in recent years as a packaging material that can alleviate the environmental impact of plastic waste.$^{1,2,3}$

Currently, edible biodegradable films and coatings find use in many applications including casings for sausages, chocolate and cheese, coatings for fruits and wax coatings for vegetables. ${ }^{4}$ As film forming agents, many scientists have studied plant proteins. Many proteins are capable of forming films that can function as replacements for synthetic packaging films. Hydrocolloids and lipids can also be used as film forming agents. Corn zein and wheat gluten are two of them. ${ }^{1,2,3}$ SPI (Soya protein isolate) has been used in combination with wheat gluten for the preparation of thin films. ${ }^{5,6}$

\footnotetext{
"Corresponding author
} 
The protein content of soya bean (38-44\%) is much higher than the protein content of cereal grains $(8-15 \%),{ }^{4,7}$ Most of the proteins in soya beans are globular. Protein present in soya bean is again classified into four fractions depending on their relative sedimentation rates. Of these, Wolf et al (1962) have found that the most important fractions are the $7 \mathrm{~S}$ and $11 \mathrm{~S}$, as the amounts of total extractable protein obtained from them are $37 \%$ and $31 \%$ respectively. ${ }^{5}$

Okamoto (1978) has studied the formation of films on the surface of soya protein solutions. Proteins are basically amino acids and during the formation of a protein chain a number of amino acids are involved. These amino acids may be hydrophilic or hydrophobic. The mechanism of film formation is believed to involve the formation of disulfide bonds. ${ }^{4}$ For the formation of films, the charged state of the proteins may be useful. Depending on the proportions of hydrophilic or hydrophobic amino acid residues present in the protein chains, the nature of the film is determined.

In addition to the film-forming polymer, a major component of an edible protein film is the plasticizer, which helps to overcome film brittleness caused by strong intermolecular forces between protein chains. Plasticizers reduce these intermolecular forces by going in between protein chains, and increasing the mobility of chains, resulting in flexibility and extensibility. ${ }^{6.8}$

The most commonly used plasticizers for soya protein isolate are glycerol, polyethylene glycols (PEG), and higher fatty acids and their derivatives.$^{8}$ Glycerin has been used successfull $\dddot{y}$ as a plasticizer for many protein films. ${ }^{6}$

Inclusion of polar plasticizers such as glycerin increases water absorption. This may be due to the additional hydrophilic groups present in the plasticizer resulting in an increase in overall hydrophilic group density of the film.

However films plasticized with glycerin develop an oily surface on storage, suggesting the migration of the plasticizer to the surface.

The aim of this study is to use SPI as a film forming agent and to study the properties of these films.

\section{METHODS AND MATERIALS}

Materials: Soya protein isolate powder supplied by Keells Food Products Ltd. was used without further purification. All other reagents used are of Analar grade.

\section{Method}

Film formation: Casting solutions were prepared ${ }^{8}$. by dissolving SPI in $80 \%$ ethanol 
$(1 \mathrm{~g}$ per $10 \mathrm{ml})$ and by heating for 5 minutes with stirring at $75 \pm 5^{\circ} \mathrm{C}$. The solution was acidified using $2 \mathrm{~mol} \mathrm{dm}^{-3} \mathrm{HCl}\left(1 \mathrm{ml}\right.$ per $6 \mathrm{ml}$ of solution). ${ }^{9}$ Glycerol $(5.00 \mathrm{ml})$ was added as a plasticizer to modify the mechanical properties of the film. Heating and stirring was continued for a further 10 minutes.

The viscous solution was spread as a thin film on a glass pad, using a thin layer chromatography (TLC) applicator (Desaga- HEIDELBERG, 120130, West Germany). The films were dried at $115 \pm 5^{\circ} \mathrm{C}$ in an air-circulated oven for a period of 8 hours. Films were peeled off the glass pad after cooling to room temperature. This method is reproducible with a high efficiency for film preparation .

Appearance: The prepared films were examined under a scanning electron microscope (SEM-TOPCON, ABT-32 JAPAN) for possible air bubbles and for homogeneity. Transparency of the prepared film was compared with LDPE film using the naked eye.

Thermal analysis: The thermal behaviour was studied using a differential scanning calorimeter (DSC) (L-DSC model TAS-100 - Rigaku, Thermal Analyzer, Japan) in normal atmosphere and at a heating rate of $10 \mathrm{~K} \mathrm{~min}^{-1}$. Small pieces of the polymer films were added together to give a sample mass of 8-10 $\mathrm{mg}$ and were loaded in to the aluminium pan with a crimped cover, in order to get good thermal contact.

Tensile strength: Tensile strength of the films was determined using a tensometer (model Houns Sield H5000M) according to ASTM D- 882 (1992). The samples (25.4 $\mathrm{mm} \times 100 \mathrm{~mm}$ ) were cut along the casting direction and in a direction perpendicular to the casting direction. Two sets of samples were conditioned at two different environments ${ }^{8,11}$ for 48 hours prior to testing. One set of samples was conditioned at $23 \pm 2{ }^{\circ} \mathrm{C}$ and at a relative humidity of $50 \pm 5 \%$, and the other set at $28 \pm 2{ }^{\circ} \mathrm{C}$ and at a relative humidity of $75 \pm 5 \%$. The first set was conditioned at accepted American Standard Test Method (ASTM D-882) and the second set was at normal laboratory conditions. Tensile strength was determined for all the four samples containing $10 \%, 15 \%, 20 \%$ and $30 \%$ of glycerol. Five replications were done for each sample.

Moisture Sorption: Moisture sorption isotherms were determined at five different relative humidities ranging from $22 \%$ to $90 \%$ according to a method described by Gennadios and Weller. ${ }^{10.11}$ From the test data the soy protein film with $10 \%$ glycerol was selected as the best film, to determine moisture content.

Samples were brought to zero moisture content initially by freeze- drying at $55^{\circ} \mathrm{C}$ and 5 millitorr for 24 hours.

The experimental data points were fitted to the isotherm predicted by the $\mathrm{GAB}$ mode ${ }^{10}$ for moisture absorption (eq.1). 
$M=\left(M_{o} C k a_{w}\right) /\left(1-K a_{w}\right)\left(1-k a_{w}+C k a_{w}\right)$

$\mathrm{M}=$ equilibrium moisture content ( $\mathrm{g}$ water / $\mathrm{g}$ dry solids); $\mathrm{a}_{\mathrm{w}}=$ water activity;

$\mathrm{M}_{\mathrm{o}}=$ monolayer moisture content; ( $\mathrm{g}$ water / $\mathrm{g}$ dry solids); $\mathrm{C}=$ Guggenheim constant; and $\mathrm{k}=$ constant correcting the properties of the multilayer molecules with respect to the bulk liquid. The accuracy of fit was evaluated by use of the mean relative deviation modulus. ${ }^{13,14}$

$P=(100 / n) \Sigma\left(\left|M_{a}-M_{p}\right| / M_{a}\right)$

Where $P$ is the mean relative deviation modulus, $M_{a}$ is the actual (experimental) moisture content; $M_{p}$ is the predicted moisture content; and $n$ is the number of observations.

A P value smaller than 5 indicates an extremely good fit; a P value between 5 and 10 represents a reasonably good fit; and a $P$ value greater than 10 shows a poor fit.

\section{RESULTS AND DISCUSSION}

\section{Appearance}

Films prepared using this method are clear, transparent, smooth and bubble free. Scanning Electron Micrographs (SEM) of Soya Protein Isolate (SPI) film and Low Density Poly Ethylene (LDPE) film show that the transparency of the SPI film is comparable with that of LDPE film. Scanning electron micrographs also confirm that it is a uniform film (Figure 1). As plasticizer concentration increases, films became soft and sticky. The best film was obtained with a plasticizer concentration of $10 \% \mathrm{w} / \mathrm{w}$.

\section{Thermal analysis}

$\mathrm{Tg}$ is highly dependent on the amount of moisture in the film and shifts towards the higher temperatures with loss of moisture. Therefore the determination of $\mathrm{Tg}$ is difficult as total moisture free samples could not be obtained. However the thermal behaviour was similar to the films from other proteins such as zein. ${ }^{15}$

\section{Tensile Properties}

Tensile strength values of plasticized soya protein films were found to be comparable with that of most of the major packaging resins ${ }^{16}$ ( Table 1 ). The values obtained in casting direction and the direction perpendicular to the casting direction did not show significant differences (Figure 2). This suggests that the tensile strength is independent of the orientation of the protein molecules. SPI is a globular protein 
and the intermolecular attractions in all directions are the same. This suggests that there may not be a significant change in the tertiary structure of the protein during dissolution and casting.

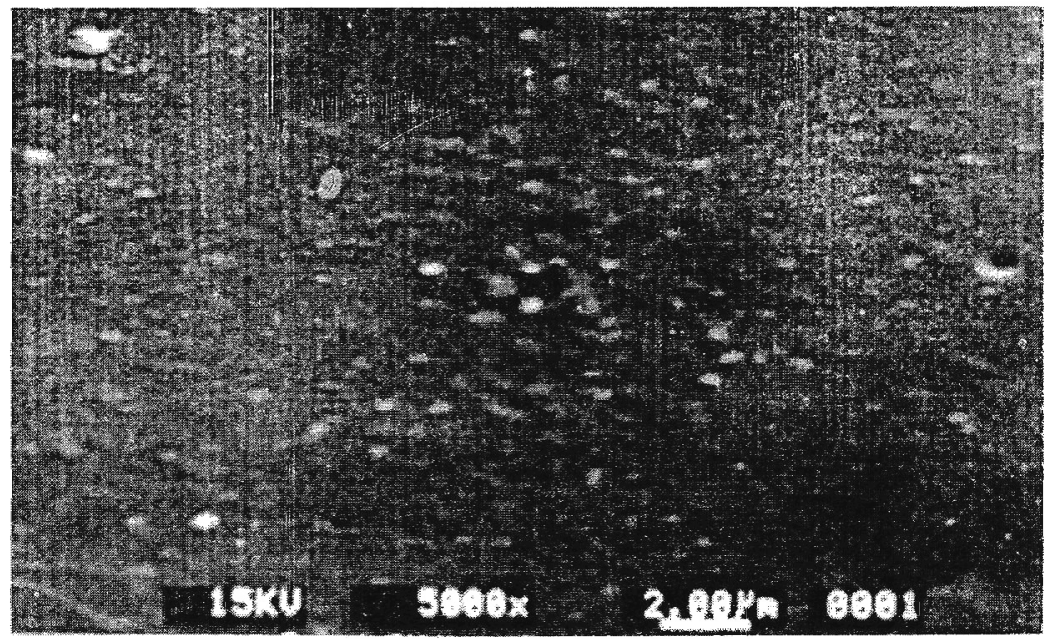

(a) Lower surface (x5000)

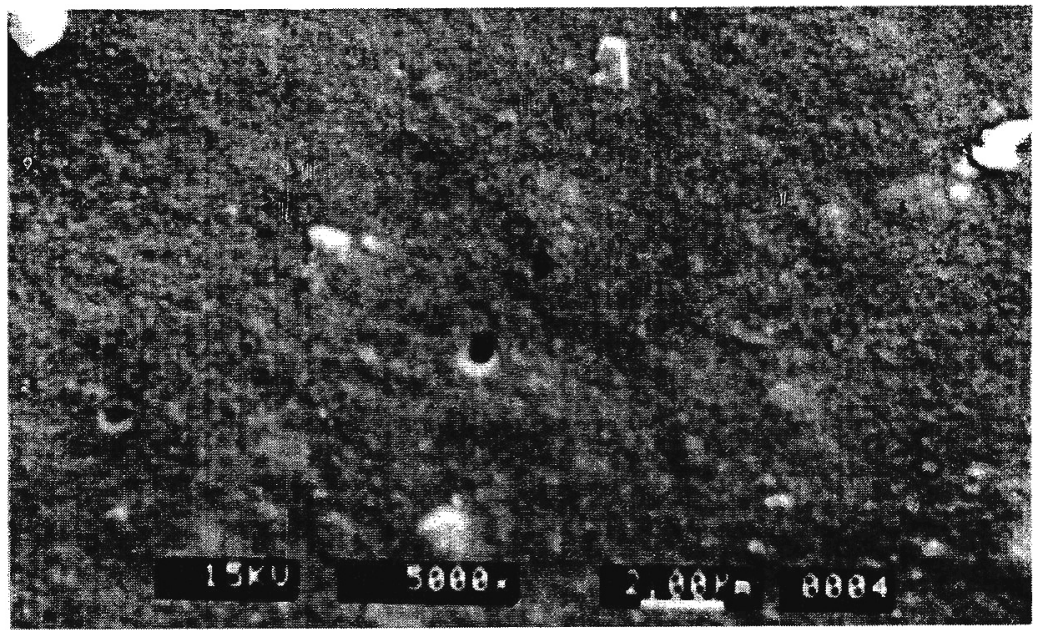

(b) Upper surface (x500)

Figure 1: Scanning electron micrograph of soya film plasticized with $10 \%$ w/w glycerol 
Highest tensile strength which is comparable with LDPE was obtained at plasticizer concentration of $10 \% \mathrm{w} / \mathrm{w}$. Tensile strength was found to decrease as the plasticizer concentration was increased. This may be due to the absorbed moisture in the protein films causing protein chains to slip over one another.

\section{Table 1: Tensile Strength data of major packaging resins}

\begin{tabular}{lc}
\hline Resins & Tensile strength (kpsi) \\
\hline High Density Poly Ethylene (HDPE) & $2.5-6$ \\
Low Density Poly Ethylene (LDPE) & $1.5-5$ \\
Linear Low Density Poly Ethylene (LDPE) & $3-8$ \\
Poly Ethylene Terepthalate (PET) & $25-33$ \\
Poly Vinyl Chloride (PVC) & $4-8$ \\
Poly Styrene (PS) & $9-11$ \\
\hline
\end{tabular}

\section{Moisture Sorption}

Moisture sorption by protein films plasticized with glycerol showed an exponential increase with increasing water activity, in the range from 0.33 to 0.84 (Fig. 3). At very low water activity, higher moisture absorption was shown and it is difficult to explain this behaviour without an in-depth study.

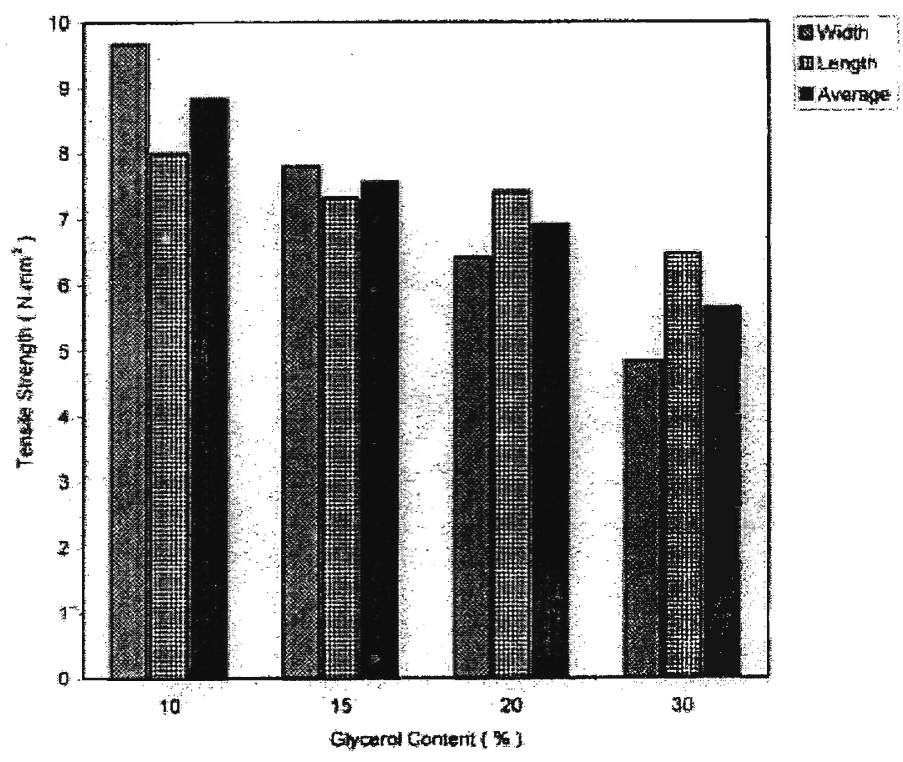

(a) At $28 \pm 2{ }^{\circ} \mathrm{C}$ temperature, $75 \pm 2 \%$ relative humidity 


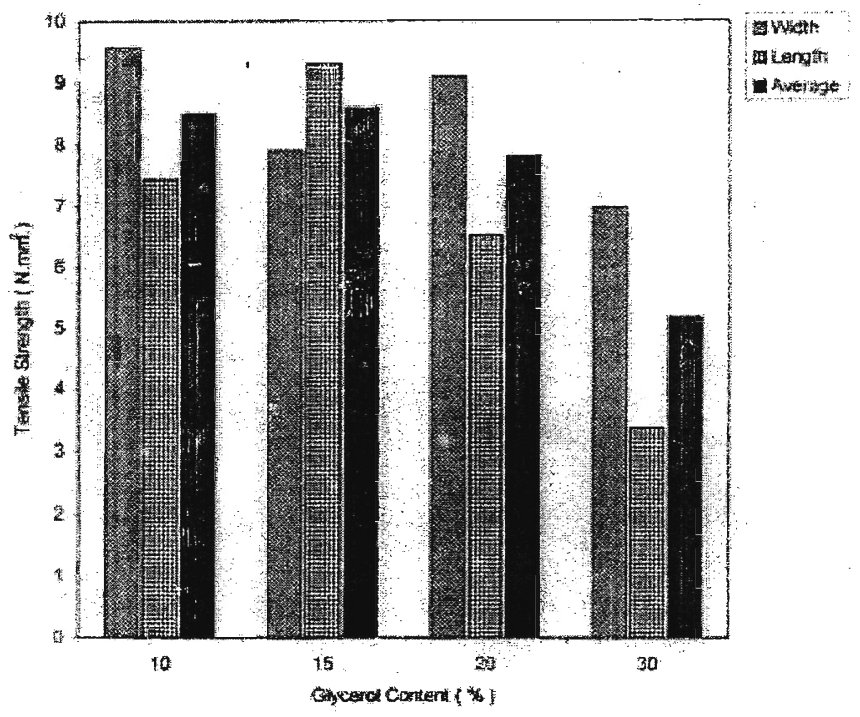

(b) At $23 \pm 2{ }^{\circ} \mathrm{C}$ temperature, $50 \pm 5 \%$ relative humidity

Figure 2: Tensile strength at $50 \pm 5 \%$ and $75 \pm 2 \%$ relative humidity, for soya protein films plasticized with different glycerol concentrations

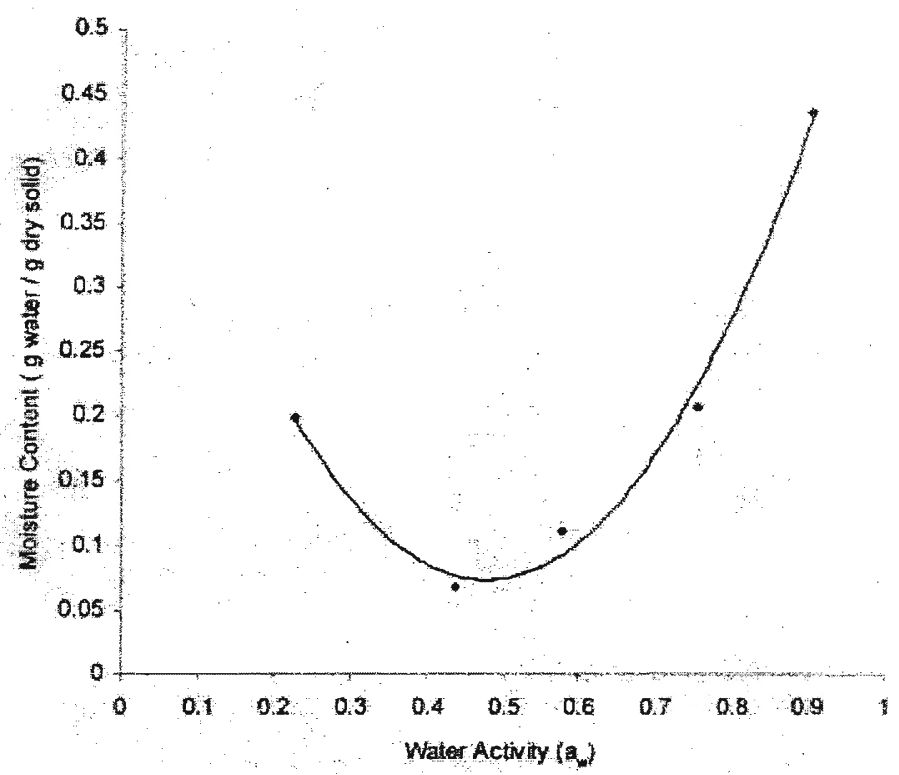

Figure 3: Fit of moisture sorption data for glycerol-plasticized $(10 \% \mathrm{w} / \mathrm{w})$ soya films to GAB model. The lines drawn are best-fit curves. 
Soya protein contains a large fraction of polar (hydrophilic) amino acids such as aspartic acid, glutamic acid and lysine, and a small fraction of nonpolar (hydrophobic) amino acids, such as leucine, proline and alanine. As water activity increases, films absorb more water due to a larger fraction of polar amino acids. ${ }^{10}$ This suggests that the moisture absorption of soya protein films depends on the hydrophilic group density of the film. Calculated mean relative deviation modulus $(\mathrm{P})$ was 9.6 (Where $\mathrm{n}=14$ ) The $\mathrm{P}$ value shows a reasonably good fit with the $\mathrm{GAB}^{\mathrm{t}}$ model.

\section{CONCLUSION}

SPI forms clear, transparent and homogeneous films. Film behaviour largely depends on the hydrophilic groups present in the protein network. Moisture absorbed through hydrophilic groups plays an important role in determining the flexibility and $\mathrm{Tg}$ of SPI films.

Like other proteins, SPI too needs the presence of a plasticizer to reduce intermolecular attractions and facilitate the movement of chains under applied stress. Tensile properties of the films formed are comparable with LDPE. Moisture absorption increases exponentially with water activity, similar to other food packaging protein films. Soya protein isolate can be successfully used as a film forming agent.

The film properties could be further improved by controlling the hydrophilic groups present in the protein / plasticizer network.

\section{Acknowledgement}

The assistance given by the Rubber Research Institute, Thelawala, with the tensile strength measurements and University of Moratuwa, Department of Materials Engineering with thermal analysis are gratefully acknowledged. Soya protein sample was supplied by Keells Food Products Ltd.

\section{References}

1 Guilbert S. \& Biquit B. (1989). L'emballage des Denrées Alimentaries Grande Consommation, (Ed by G. Bureau \& J.L Mutton ) pp 320. Technique et. Documentation. Paris, France.

2 Guilbert S. (1986). Food packaging and preservation: theories and Practice (Ed M.Mathlouthi.).pp 377. Applied Science Publishers, New York.

3 Kester J.J. \& Fennema O. (1986). Edible films and coatings. : A review Food Technology. 40(12) : 47. 
4 Crochet J.M., Baldwin E.A. \& Nisperos-Carriedo M.O. (1994). Edible films to improve food quality.pp.1-21, 201-257. Technomic Publishing Company ,U.S.A.

5 Gennadios A. \& Weller C.L. (1990). Edible films and coatings from Wheat and Corn proteins. Food Technology. 44(10) : 63-69.

6 Gennadios A. \& Weller C.L. (1991). Edible films and coatings from protein films. Cereal Food World . 36: 1004-1009.

7 Bewley J.D. \& Black M. (1984) Seeds. physiology of development and germination : 268-269

Thillekeratne M. \& Easteal A.J. (2000). Modification of Zein films by incorporation of polyethylene glycols. Journal of Polymer Science. 49: 127134.

9 Gennadios A., Brandenburg A.H., Wellar C.L. \& Testin. R.F. (1993e). Effect of $\mathrm{pH}$ on properties of Wheat glutein and soy protein isolate films. Journal of Agriculture food chemistry. 41 (11) :1835-1839.

10 Gennadios A.\& Wellar C.L.(1994). Moisture adsorption by Grain Protein films. Transaction of the American Society of Agricultural Engineers. 37: 535-539.

11 Gennadios A., Park H.J. \& Wellar C.L. (1994). Relative humidity and temperature effects on tensile strength of edible protein and cellulose ether films. Transaction of the American Society of Agricultural Engineers (ASAE). 36(6) :1867-1872.

12 Labuza T.P. (1968). Sorption phenomena in foods. Food Technology. 22(3): 263272 .

13 Gencturk M.B., Bakshi A.S., Hong Y.C. \& Labuza P. (1986). Moisture Transfer Properties of wild rice. Journal of Food Processing Engineering.8:243-261.

14 Lomauro C.J., Bakki A.S. \& Labuza T.P. (1985). Evaluation of food moisture sorption isotherm equations. part I. Fruit, Vegetable \& meat products. Lebeusm Wiss Technology. 18 : 111.

15 Matveev Y.I. \& Grinberg V.B.(1997). Glass transition temperature of proteins. Calculation based on the additive contribution method and experimental data. Food Hydrocolloids 11(2): 125-133

16 Jenkins W.A. \& Harrington J.P. (1991). Packaging foods with plastics.pp.6061. Technomic Publishing Co.Inc. Lancaster, U.S.A. 